\title{
FIRE EFFECTS ON SOIL FUNGI IN A CERRADO VEGETATION AREA ACCORDING TO THE COLLECTION PERIOD
}

\author{
Gil Rodrigues dos Santos ${ }^{1 *}$, Sandra Ruth Saavedra Magallanes ${ }^{2}$, Fernando Machado Haesbaert ${ }^{2}$, Eliane \\ Aparecida Rotili ${ }^{2}$, Jader Nunes Cachoeira², Marcos Giongo ${ }^{2}$ \\ ${ }^{1 *}$ Federal University of Tocantins - Gurupi, Tocantins, Brazil, e-mail: gilrsan@mail.uft.edu.br \\ ${ }^{2}$ Federal University of Tocantins- Gurupi, Tocantins, Brazil, e-mail: biologa.saavedra@ gmail.com, fernandomh@mail.uft.edu.br, \\ elianerotili@mail.uft.edu.br, jadernunes@uft.edu.br, giongo@uft.edu.br
}

Received for publication: 24/09/2018 - Accepted for publication: 28/02/2019

\begin{abstract}
Resumo
Efeitos do fogo nos fungos do solo em área de vegetação de cerrado em função do tempo de coleta. $\mathrm{O}$ Cerrado é reconhecido pela sua biodiversidade, mas atualmente é considerado um bioma ameaçado. Este trabalho objetivou avaliar os impactos do fogo de baixa intensidade sobre a abundância e riqueza das comunidades de fungos habitantes num Latossolo Vermelho Amarelo em Cerrado Sensu Stricto. Foram definidos cinco tratamentos em parcelas controle e queimadas, que representam as coletas do solo em função do tempo pós queima prescrita em diferentes épocas. Os efeitos do fogo foram analisados nas camadas de 0-5 e 15-20 cm de profundidade do solo. Para análise estatística foram utilizados os índices de Shanon-Wiener, Simpson e Berger-Parker. Foi constatada redução significativa (ANOVA teste de Dunnett p> 0,05) de 33,3\% na abundância total (UFC. $\left.\mathrm{g}^{-1}\right)$, na camada superficial e perfil mais profundo do solo $(15-20 \mathrm{~cm}$ ) das parcelas queimadas em relação às parcelas controle. Porém, houve recolonização dos fungos aos 2 meses após a queima. Foram encontrados 21 gêneros de fungos, sendo verificado maior diversidade nas parcelas queimadas em comparação às não queimadas. $\mathrm{O}$ índice de Shanon-Wiener máximo foi $\mathrm{H}^{\prime}=0,85$ na profundidade $15-20 \mathrm{~cm}$ nas parcelas queimadas. Quanto ao índice de dominância foi encontrado valor máximo de $70 \%$ pelo gênero Aspergillus (no tratamento antes da queima na profundidade $15-20 \mathrm{~cm}$ ). As flutuações na diversidade de fungos após a queima não foram afetadas pelo fogo, mas sim pelos índices pluviométricos nos tratamentos após a queima. A equidade foi uniforme e mostrou diferenças na riqueza numérica nas parcelas queimadas e controle. A precipitação pluviométrica teve grande impacto na rapidez de recuperação dos fungos.
\end{abstract}

Palavras-chave: Savana, microrganismos, diversidade, queima prescrita.

\begin{abstract}
The Cerrado is recognized for its biodiversity, but is currently considered a threatened biome. This study aimed to evaluate the impacts of low-intensity fire on the abundance and richness of fungal communities in a Red Yellow Latosol in Sensu Stricto Cerrado. Five treatments were defined in control and burned plots, which represent the soil collections as a function of the periods after prescribed firing. The fire effects were evaluated in the 0-5 and 15-20 cm layers of soil depth. For statistical analysis, the Shanon-Wiener, Simpson and Berger-Parker indexes were used. A significant reduction of $33.3 \%$ was observed (ANOVA; Dunnett Test $\mathrm{p}>0,05)$ in total abundance (UFC. $\left.\mathrm{g}^{-1}\right)$, in the superficial layer and in the deeper soil profile $(15-20 \mathrm{~cm})$ of the burned plots when compared to the control plots. However, it was observed a fungi recolonization at 2 months after burning. A total of 21 fungi genera were found, and more diversity was observed in the burned plots compared to non-burned. The maximum Shanon-Wiener index was $H^{\prime}=0,85$ in the $15-20 \mathrm{~cm}$ depth for the burned plots. For the dominance index, a maximum value of $70 \%$ was observed for the Aspergillus genus (in the treatment before burning for the $15-20 \mathrm{~cm}$ depth). The fluctuations in the diversity of fungi after burning were not affected by the fire, but by the rainfall indexes in the treatments after burning. The equity was uniform and showed differences in the numerical richness in burned plots and control. Rainfall has a great impact on the fungal recovery speed.
\end{abstract}

Keywords: Savannah, microrganisms, diversity, prescribed firing.

\section{INTRODUCTION}

Fire is part of many natural systems, mainly in temperate ecosystems in both hemispheres, being in the Cerrado biome one of the most frequent practices of vegetation management. In the last 30 years, the frequency of fire increased in several places in Brazil, mainly in the north of the Minas Gerais, west of Bahia, Piauí and east of Tocantins States, due to the growth of forestry, livestock and mainly agricultural activities that use the cutting and burning techniques (BORGES et al., 2016). Despite its importance in the understanding and development of ecosystems, the consequences of fire on the soil microbiota and its diversity have been little studied and, therefore, practically unknown.

FLORESTA, Curitiba, PR, v. 50, n. 1, p. 1113 - 1122, jan/mar 2020.

Santos, G. R. et.al.

ISSN eletrônico 1982-4688

DOI: $10.5380 /$ rf.v50 i1.61754 
The impacts of this practice on the biochemical properties of the soil varies depending on the ecosystem and characteristics of the burn, such as intensity, duration and frequency. Direct heat transferred to the soil during burning can lead to microbial mortality. Regarding the fungi, it is known that some groups are more sensitive to temperature elevation than others, which may result in the selective elimination of specific groups, causing changes in the community and frequency of these soil organisms (SHEN et al., 2016).

Although the use of fire as a land management tool is a common practice in Brazil, there are few studies carried out in the cerrado biome of Tocantins and other States that are in the process of expanding the country's agricultural frontier. Thus, it is evident the need of studies that show the effects of burning on the fungi inhabitants and decomposers of soil substrates, in order to subsidize actions of management of the areas destined to agricultural activities, with the intention of establishing more preserved agropastoral systems as well as to reduce soil damages. It is believed that the prescribed burning can affect the fungal population of soils at different depths.

Thus, the present study aimed to evaluate the impacts of a low intensity burn in Cerrado vegetation, based on the abundance and diversity of the soil fungi at different depths.

\section{MATERIAL AND METHODS}

The study was carried out at the Verdes Mares Farm in the Sucupira municipality, Tocantins State, Brazil, located at $11^{\circ} 59$ ' 36 "S of latitude and $48^{\circ} 58^{\prime} 15^{\prime \prime} \mathrm{W}$ of longitude, with an altitude of 257 meters. According to the classification of Thornthwaite, the location is inserted in the C2wA'a climatic region, characterized by having a humid climate, with moderate water deficiency. The rainy season is well defined (from October to April) with $75 \%$ of precipitation in the period, followed by a dry season when the occurrence of forest fires is high. The average annual rainfall varies from 1,600 to $1,800 \mathrm{~mm}$ and the average annual temperature varies from 26 to $27^{\circ} \mathrm{C}$. The relative humidity of the annual average air is $70 \%$, and in the rainy season average rates are higher than $80 \%$ and in the dry period around 50\% (SEPLAN, 2012).

The soil of the studied area is a Yellow Red Latosol (EMBRAPA, 2013). In the surroundings of the farm, the landscape is dominated by a mosaic of crops of soy and pastures. The location of the experiment do not show evidences of anthropic interference, being covered by a Cerrado vegetation classified as a Sensu Stricto Cerrado (RIBEIRO; WALTER, 2008).

The prescribed burnings were carried out in October of 2015, at times between 11:05 am and 20:05 pm, always in favor of the wind. Burnings were carried out in 20 plots, with each experimental plot presenting dimensions of $10 \mathrm{~m}$ in width and $20 \mathrm{~m}$ in length, with fireplaces of $0.50 \mathrm{~m}$. Each plot contained a control treatment, which consisted in the collection of soil before the firing execution. To measure the propagation velocity $\left(\mathrm{m} . \mathrm{s}^{-1}\right)$ and flames height $(\mathrm{m})$, a demarcation was carried out on every two meters in the plots length direction. Data collection of fire behavior and determination of the moisture content of the fuel material followed the methodologies recommended by Batista et al. (2013).

The determination of the forest fuel amount was based on the destructive method proposed by Brown et al. (1982). Before the firing, the mean air temperature $\left({ }^{\circ} \mathrm{C}\right)$, relative air humidity $(\%)$ and average wind speed $\left(\mathrm{ms}^{-1}\right)$ were determined from a portable meteorological station (model Kestrel® 4000), installed in the experiment area. The intensity of the fire line was obtained by the equation proposed by Byram (1959), according to Equation 1:

$$
I=H * w * r
$$

In which: $\mathrm{H}=$ the combustion heat of the material $\left(\mathrm{kcal} \mathrm{kg}^{-1}\right) ; \mathrm{w}=$ the forest fuel amount $\left(\mathrm{kg}_{\mathrm{m}} \mathrm{m}^{-2}\right)$ and $\mathrm{r}$ $=$ fire propagation velocity $\left(\mathrm{m} . \mathrm{s}^{-1}\right)$. The calorific value $(\mathrm{H})$ used was $3,705 \mathrm{kcal}_{\mathrm{kg}} \mathrm{kg}^{-1}$, a value frequently used to verify the fire behavior in savannas, as reported in the literature (GRIFFIN, FRIEDEL, 1984).

The treatments were represented by the time of the soil samples collected after the prescribed burning, being: Control (T0) - before burning (end of dry season); Treatment 1 (T1) - 24 hours after burning (end of dry season); Treatment 2 (T2) - 2 months after burning (beginning of rainy season); Treatment 3 (T3) - 4 months after burning (middle of the rainy season); Treatment 4 (T4) - 6 months after burning (end of rainy season) and; Treatment 5 (T5) - 8 months after burning (beginning of drought).

During the period of the experiment, accumulated precipitation data were obtained from the National Meteorology Institute database (INMET, 2015). In order to evaluate the impact of the prescribed burning on the fungal populations in the different layers of the soil, three random samples were collected at $0-5 \mathrm{~cm}$ and 15-20 $\mathrm{cm}$ depths, obtaining a composed sample of each plot. According to the recommendation of Díaz-Raviña et al. (2012), the samples were stored in plastic bags and packed in foam boxes to maintain the temperature around 4 ${ }^{\circ} \mathrm{C}$.

FLORESTA, Curitiba, PR, v. 50, n. 1, p. 1113- 1122, jan/mar 2020 
In the laboratory, the microorganisms present in the soil samples were evaluated in three replicates by the plate dilution method, with a dilution factor of $10^{-4}$. The culture medium was composed of Potato $(250 \mathrm{~g})+$ Dextrose $(20 \mathrm{~g})+$ Agar - agar $(20 \mathrm{~g})$, with antibiotic Chloramphenicol $50 \mathrm{mg}\left(0.2 \mathrm{~g} . \mathrm{L}^{-1}\right)$ to avoid bacterial contamination. A volume of the solution was spread on the surface of the culture medium with the aid of a Drigalski spatula. The plates were sealed with PVC film, identified and incubated for 72 hours. After this period, the number of colonies on the surface of the culture medium was counted for five days. Then, the conversion to Colony Forming Units (CFU.g $\mathrm{g}^{-1}$ ) were made, as proposed by Dhingr and Sinclair (1985) and according to the Equation 2:

$$
U F C g^{-1}=\left(N C^{1} / F D{ }^{1 / V}\right) / P
$$

In which: $\mathrm{NC}$ is the number of $\mathrm{CFU}$ on the plate; FD the dilution factor; $\mathrm{V}$ the inoculated volume on the plate; $\mathrm{P}$ is the weight of the sample.

All the collected fungi were identified at the genus level as a function of the assimilation, reproduction and resistance structures formed in the medium. The data were submitted to variance analysis (ANOVA) applied between the control and burned plots. When ANOVA indicated a significant difference $(\mathrm{P} \leq 0.05)$, the Dunnett test was applied, with a confidence interval of $95 \%$. The chi-square test was used to evaluate differences before and after the fire use $(24 \mathrm{~h})$ between treatments at two soil depths. For the dats analysis, the Margalef, ShanonWiener, Simpson, Berger-Parker (MAGGURAN, 2011) and Jaccard indexes were estimated. The Margalef index is a measure used to estimate the biodiversity of a community based on the numerical distribution of individuals of different species as a function of the total number of individuals in the analyzed sample. The higher the index value, the greater the diversity of the sampled community (KANIESKI et al., 2012).

To determine the diversity, equity and dominance, the data were processed in the software DiVES v3.0 (RODRIGUES, 2015). The Jaccard coefficient of similarity was estimated using the XLSTAT 2017 software.

\section{RESULTS}

Before burning (T0), at the end of the dry season, the abundance CFU.g ${ }^{-1}$ in the control plots were $47,970 \pm 21,056.59$ and 56,040 $\pm 15,079.3$, at the 0-5 cm and 15-20 cm depths, respectively. The differences between the two values were not statistically significant according to the ANOVA test. As for the chi-square test, the contingency of the individuals showed dependence $(\mathrm{p}<0.0001)$ among all evaluated plots and depths (Table $1)$.

Table 1. Abundance of Colony Forming Units $\left(\mathrm{CFU} \cdot \mathrm{g}^{-1}\right)$ in a PDA medium from two cerrado soil depths submitted to fire treatments and evaluated at different times of collection in the municipality of Sucupira, Tocantins, Brazil, from 2015 to 2016.

Tabela 1. Abundância de Unidades Formadoras de Colônias (UFC $\mathrm{g}^{-1}$ ) formadas em meio de cultura BDA proveniente de duas profundidades de solo de Cerrado submetido à queimada e avaliado em diferentes épocas, no município de Sucupira, Tocantins, nos anos de 2015 a 2016.

\begin{tabular}{l|c|c}
\hline \multirow{2}{*}{ Treatment } & \multicolumn{2}{|c}{ Depth } \\
\cline { 2 - 3 } & $0-5 \mathrm{~cm}$ & $15-20 \mathrm{~cm}$ \\
\hline Before burn (T0) & $47.970 \pm 21.056,59$ & $56.040 \pm 15.079,3$ \\
24 hours after burn (T1) & $32.345 \pm 14.353,30 *$ & $11.905 \pm 9.463,70 *$ \\
2 months after burn (T2) & $107.010 \pm 56.162,59$ & $105.685 \pm 74.620,48$ \\
4 months after burn (T3) & $109.640 \pm 47.272,9$ & $44.705 \pm 41.416,78$ \\
6 months after burn (T4) & $77.520 \pm 40.575,81$ & $63.350 \pm 41.538,82$ \\
8 months after burn (T5) & $74.845 \pm 53.340,72$ & $35.425 \pm 77.057,97$ \\
\hline
\end{tabular}

Averages \pm standard deviations followed by $*$ indicate significant statistical difference between the means of the plots submitted to the prescribed burning and the control plot by ANOVA and Dunnett's test ( $p>0.05$ ). Rainfall distribution in the treatments, where: T0: end of dry season; T1: end of dry season; T2: beginning of rainy season; T3: middle of rainy season; T4: end of rainy season; T5: beginning of dry season.

It was observed, for the treatment with two months after burning (T2) a recover of the mivrofungi communities with values of 107,010 $\pm 56,162.59$ CFU.g ${ }^{-1}$ at the first $5 \mathrm{~cm}$ of soil and of 105,685 $\pm 74,620.48$ of CFU.g ${ }^{-1}$ at the $15-20 \mathrm{~cm}$ soil depth.

Table 2. Contingencies of the populations of fungi microflora as a function of pre-and post-firing samples prescribed from the vegetation, in the layers of $0-5 \mathrm{~cm}$ and $15-20 \mathrm{~cm}$ of soil depths.

Tabela 2. Contingências das populações de microflora fúngica em função de amostragens pré e pós queima prescrita da vegetação, nas camadas de solo de $0-5 \mathrm{~cm}$ e $15-20 \mathrm{~cm}$ de profundidade.

FLORESTA, Curitiba, PR, v. 50, n. 1, p. 1113 - 1122, jan/mar 2020.

Santos, G. R. et.al.

ISSN eletrônico 1982-4688

DOI: 10.5380/rf.v50 i1.61754 


\begin{tabular}{|c|c|c|c|c|c|c|c|c|}
\hline \multicolumn{5}{|l|}{ T0: Before burn } & \multicolumn{4}{|c|}{ T1: 24 hours after burn } \\
\hline Genre & SQP1 & QP1 & SQP2 & QP2 & SQP1 & QP1 & SQP2 & QP2 \\
\hline Aspergillus & 11083 & 15442 & 2750 & 54500 & 12183 & 4971 & 2200 & 2600 \\
\hline Chaetonium & 550 & 1414 & - & 707 & 550 & 942 & - & 235 \\
\hline Cladosporium & 12750 & 8778 & 1100 & 2835 & 12750 & 950 & 1100 & 1657 \\
\hline Curvularia & - & - & - & - & - & 235 & - & - \\
\hline Fusarium & 550 & 1657 & - & 235 & 550 & - & - & - \\
\hline Mucor & - & 942 & 1650 & 1650 & 1100 & 707 & 1100 & 235 \\
\hline Penicillium & 11050 & 12585 & 2766,6 & 5921 & 11066 & 3542 & 3866 & 3071 \\
\hline Phoma & - & - & - & - & - & - & - & 1650 \\
\hline Pythium & 450 & 4971 & - & 235 & 4400 & 11164 & - & 2128 \\
\hline Rhizoctonia & - & 235 & - & 3314 & - & - & - & - \\
\hline Synchytrium & - & 235 & - & 4985 & - & 3314 & - & - \\
\hline Trichoderma & - & 1657 & - & 235 & - & 1892 & - & 942 \\
\hline Verticillium & 550 & 2357 & 550 & 1657 & - & 235 & 550 & 707 \\
\hline \multicolumn{5}{|c|}{ T2: 2 months after burn } & \multicolumn{4}{|c|}{ T3: 4 months after burn } \\
\hline Genre & SQP1 & QP1 & SQP2 & QP2 & SQP1 & QP1 & SQP2 & QP2 \\
\hline Alternaria & - & - & - & - & - & 942 & - & - \\
\hline Aspergillus & 70450 & 41392 & 47183 & 43535 & 4550 & 49485 & 4433 & 11407 \\
\hline Aureobasidium & - & - & - & - & - & - & 550 & - \\
\hline Chaetonium & - & 714 & - & 471 & - & 950 & 1650 & 707 \\
\hline Cladosporium & 12766 & 19492 & 11650 & 2128 & 4433 & 1657 & - & 1892 \\
\hline Curvularia & - & - & - & - & - & 1657 & - & 235 \\
\hline Fusarium & - & - & - & 2614 & 4433 & 2364 & 1100 & 942 \\
\hline Mortierella & - & - & - & - & - & 471 & - & 942 \\
\hline Mucor & - & 6892 & 3316 & 714 & 2766 & 3085 & 2766 & 3321 \\
\hline Penicillium & 29400 & 22350 & 7766 & 13307 & 24966 & 31400 & 550 & 5685 \\
\hline Phialophora & - & - & - & - & - & 235 & - & 1185 \\
\hline Phoma & 550 & - & 31083 & 31871 & - & - & 5000 & - \\
\hline Pythium & - & 4514 & - & 1657 & 3866 & 6878 & 6100 & 3800 \\
\hline Rhizopus & - & - & - & - & - & - & - & 707 \\
\hline Synchytrium & 1100 & 3085 & 2766 & 6171 & - & 5928 & 2750 & 14271 \\
\hline Trichoderma & - & - & - & - & 7183 & 9978 & - & - \\
\hline Verticillium & - & 714 & - & - & - & - & - & - \\
\hline \multicolumn{5}{|c|}{ T4: 6 months after burn } & \multicolumn{4}{|c|}{ T5: 8 months after burn } \\
\hline Genre & SQP1 & QP1 & SQP2 & QP2 & SQP1 & QP1 & SQP2 & QP2 \\
\hline Alternaria & 1666 & 471 & - & - & - & - & - & - \\
\hline Aspergillus & 72200 & 37585 & 20516 & 34485 & 29966 & 55200 & 6100 & 15442 \\
\hline Bipolaris & - & - & - & - & - & 1178 & - & - \\
\hline Chaetonium & 2750 & 1885 & 1666 & 4742 & 2216 & 5685 & - & 24521 \\
\hline Cladosporium & - & 1428 & 4983 & 2378 & 4416 & 2135 & - & 707 \\
\hline Curvularia & - & - & 550 & 471 & - & - & - & - \\
\hline Fusarium & 550 & 235 & - & - & - & - & - & - \\
\hline Mucor & - & 707 & - & - & - & 471 & - & - \\
\hline Papularia & - & 235 & - & - & - & - & - & - \\
\hline Penicillium & 550 & 4278 & 550 & 235 & 550 & 1178 & - & 1650 \\
\hline Pestalotia & 550 & - & - & 3785 & - & 471 & 550 & 714 \\
\hline Phoma & 6650 & 2842 & 1100 & 1185 & 550 & 471 & 500 & - \\
\hline Pythium & 12183 & 12342 & 12200 & 13314 & - & 7592 & - & 1178 \\
\hline Rhizoctonia & - & 235 & - & - & - & - & - & - \\
\hline Rhizopus & - & - & - & - & - & - & - & - \\
\hline Synchytrium & 1100 & 4035 & - & 6392 & 4966 & 4507 & - & 707 \\
\hline Trichoderma & - & 2371 & - & 1657 & 7216 & 6642 & 1650 & 1892 \\
\hline Verticillium & - & - & - & 3085 & - & - & - & - \\
\hline
\end{tabular}

$\mathrm{SQ}=$ not burned area; $\mathrm{Q}=$ burned area; $\mathrm{P} 1=$ depth $1(0-5 \mathrm{~cm}) ; \mathrm{P} 2=$ depth $2(15-20 \mathrm{~cm})$. 
Table 2 presents the contingency of fungal microflora populations as a function of the evaluation period before and after the vegetation burn, in the $0-5 \mathrm{~cm}$ and $15-20 \mathrm{~cm}$ soil layers. The results indicated that the majority of the fungal community suffered constant variation in its composition in relation to the evaluated characteristics. In all treatments there were differences in the amounts and types of fungi.

Regarding the effects of burning on the presence-absence of genera in the different treatments, the results are presented in Table 3. Twenty-one genera were identified throughout the study period, covering the two sampled soil depths.

Table 3. Presence-absence of genera according to the evaluation period after the vegetation burn, in the $0-5 \mathrm{~cm}$ and $15-20 \mathrm{~cm}$ soil layers.

Tabela 3. Presença-ausência de gêneros em função da época de avaliação pré e após a queima da vegetação, nas camadas de 0-5 cm e 15-20 cm de profundidades do solo.

\begin{tabular}{|c|c|c|c|c|c|c|c|c|c|c|c|c|}
\hline \multirow{4}{*}{ Fungi genus } & \multicolumn{12}{|c|}{ Treatments - 0-5 cm Depth } \\
\hline & \multicolumn{2}{|c|}{ T0 } & \multicolumn{2}{|c|}{ T1 } & \multicolumn{2}{|c|}{ T2 } & \multicolumn{2}{|c|}{ T3 } & \multicolumn{2}{|c|}{ T4 } & \multicolumn{2}{|c|}{ T5 } \\
\hline & $\mathbf{C}$ & $\mathbf{Q}$ & $\mathbf{C}$ & $\mathbf{Q}$ & $\mathbf{C}$ & $\mathbf{Q}$ & $\mathbf{C}$ & $\mathbf{Q}$ & $\mathbf{C}$ & $\mathbf{Q}$ & $\mathbf{C}$ & $\mathbf{Q}$ \\
\hline & \multicolumn{12}{|c|}{ 0-5cm Depth } \\
\hline Alternaria & - & - & - & - & - & - & - & $x$ & $\times$ & $\times$ & - & - \\
\hline Aspergillus & $x$ & $x$ & $\times$ & $x$ & $x_{+}$ & $x$ & $x$ & $x$ & $x_{+}$ & $x_{+}$ & $x_{+}$ & $x_{+}$ \\
\hline Aureobasidium & - & - & - & - & - & - & - & $x$ & - & - & - & - \\
\hline Bipolaris & - & - & - & - & - & - & - & - & - & - & - & $x$ \\
\hline Chaetonium & $\times$ & $x$ & $x$ & $x$ & - & $x$ & - & $x$ & $x$ & $x$ & $x$ & $x$ \\
\hline Cladosporium & $\times$ & $x$ & $x$ & $x$ & $x$ & $x$ & $x$ & $x$ & - & $x$ & $x$ & $x$ \\
\hline Curvularia & - & - & - & $x$ & - & - & - & $x$ & - & - & - & - \\
\hline Fusarium & $x$ & $x$ & $x$ & - & - & $x$ & $x$ & $x$ & $\times$ & $\times$ & - & - \\
\hline Mortierella & - & - & - & - & - & - & - & $x$ & - & - & - & - \\
\hline Papularia & - & - & - & - & - & - & - & - & - & $\times$ & - & - \\
\hline Penicillium & $\times$ & $x$ & $\times$ & $x$ & $x$ & $x$ & $x$ & $x$ & $\times$ & $\times$ & $x$ & $x$ \\
\hline Pestalotia & - & - & - & - & - & - & - & - & $x$ & - & - & $x$ \\
\hline Phialophora & - & - & - & - & - & - & - & $x$ & - & - & - & - \\
\hline Phoma & - & - & - & - & $x$ & - & - & - & $\times$ & $\times$ & $x$ & $x$ \\
\hline Pythium & $\times$ & $x$ & $x$ & $\times$ & - & $\times$ & $x$ & $x$ & $\times$ & $\times$ & - & $x$ \\
\hline Rhizoctonia & - & $x$ & - & - & - & - & - & - & - & $\times$ & - & - \\
\hline Rhizopus & - & - & - & - & - & $\times$ & - & $x$ & - & - & - & - \\
\hline Synchytrium & - & $x$ & - & $x$ & $x$ & $x$ & $x$ & $x$ & $\times$ & $\times$ & $x$ & $x$ \\
\hline Trichoderma & - & $x$ & - & $\times$ & - & $\times$ & $\times$ & $\times$ & - & $\times$ & $x$ & $x$ \\
\hline Verticillium & $\times$ & $x$ & $\times$ & $\times$ & - & $x$ & - & - & - & - & - & - \\
\hline \multicolumn{13}{|c|}{ Treatments- Depth $15-20 \mathrm{~cm}$ Depth } \\
\hline Aspergillus & $\times$ & $x_{+}$ & $\times$ & $x$ & $x$ & $x$ & $x$ & $x$ & $x$ & $x$ & $x_{+}$ & $x$ \\
\hline Aureobasidium & - & - & - & - & - & - & $x$ & - & - & - & - & - \\
\hline Chaetonium & - & $x$ & - & $x$ & - & $x$ & $x$ & $x$ & $\times$ & $\times$ & - & $x_{+}$ \\
\hline Cladosporium & $x$ & $x$ & $x$ & $x$ & $x$ & $x$ & - & $x$ & $x$ & $x$ & - & $x$ \\
\hline Curvularia & - & - & - & - & - & $x$ & - & $x$ & $\times$ & $\times$ & - & - \\
\hline Fusarium & - & $x$ & - & - & $x$ & $x$ & $x$ & $x$ & - & - & - & - \\
\hline Mortierella & - & - & - & - & - & - & - & $x$ & - & - & - & - \\
\hline Mucor & $\times$ & $x$ & $x$ & $x$ & $x$ & $\times$ & $x$ & $x$ & - & - & - & - \\
\hline Penicillium & $x$ & $x$ & $\times$ & $x$ & $x$ & $x$ & $x$ & $x$ & $\times$ & $\times$ & - & $x$ \\
\hline Pestalotia & - & - & - & - & - & - & - & - & - & $\times$ & $x$ & $x$ \\
\hline Phoma & - & $x$ & - & $x$ & $x$ & $x$ & $x$ & - & $\times$ & $\times$ & $x$ & - \\
\hline Pythium & - & $x$ & - & $x$ & $x$ & $\times$ & $x$ & $x$ & $\times$ & $\times$ & - & $x$ \\
\hline Synchytrium & - & $x$ & - & - & $x$ & $x$ & - & $x$ & $x$ & $x$ & - & $x$ \\
\hline Trichoderma & - & $x$ & - & $x$ & - & - & $x$ & $\times$ & - & $\times$ & $x$ & $x$ \\
\hline Verticillium & $x$ & $x$ & $x$ & $x$ & - & - & - & - & - & $x$ & - & - \\
\hline
\end{tabular}

$\mathrm{x}=$ Presence; - = Absence; $\mathrm{C}=$ control plots; $\mathrm{Q}=$ Prescribed burn plots; $\times$ followed by + : dominant genre according to the Berger-Parker dominant index with $\mathrm{D}$ above 0.5

As can be seen in Table 4, regarding the richness and diversity, equity and dominance indexes, some treatments presetned a variation for the two evaluated soil depths. For the equity values in the $0-5 \mathrm{~cm}$ depth, no changes were noticed and for the 15-20 depth, it was observed a variation for both indexes and for the Simpson's

FLORESTA, Curitiba, PR, v. 50, n. 1, p. 1113 - 1122, jan/mar 2020.

Santos, G. R. et.al.

ISSN eletrônico 1982-4688

DOI: $10.5380 /$ rf.v50 i1.61754 
dominance. On the other hand, the Margalef and Shanon-Wiener diversity indexes in the prescribed burning plots presented higher values in the T3 and T4 treatments, with Margalef index showing a lower value at the T2.

Table 4. Richness and diversity, equity and dominance indexes for the fungi genre for the treatments.

Tabela 4. Riqueza e índices de diversidade, equidade e dominância de gêneros nos tratamentos.

\begin{tabular}{c|c|c|c|c|c|c|c|c|c|c|c|c}
\hline \multirow{2}{*}{ T/P } & \multicolumn{2}{|c|}{ S } & \multicolumn{2}{c|}{$\mathbf{D}_{\mathbf{M g}}$} & \multicolumn{2}{c|}{$\mathbf{H}^{\prime}$} & \multicolumn{2}{c|}{$\mathbf{J}^{\prime}$} & \multicolumn{2}{|c|}{$\boldsymbol{\lambda}$} & \multicolumn{2}{|c}{ D } \\
\cline { 2 - 12 } & $\mathbf{1}$ & $\mathbf{2}$ & $\mathbf{1}$ & $\mathbf{2}$ & $\mathbf{1}$ & $\mathbf{2}$ & $\mathbf{1}$ & $\mathbf{2}$ & $\mathbf{1}$ & $\mathbf{2}$ & $\mathbf{1}$ & $\mathbf{2}$ \\
\hline T0 C & 8 & 5 & 3.71 & 3.40 & 0.68 & 0.61 & 0.76 & 0.88 & 0.23 & 0.22 & 0.30 & 0.33 \\
T0 Q & 11 & 11 & 4.30 & 3.99 & 0.80 & 0.50 & 0.77 & 0.48 & 0.20 & 0.52 & 0.31 & 0.71 \\
T1 C & 8 & 5 & 3.70 & 3.32 & 0.68 & 0.61 & 0.75 & 0.87 & 0.23 & 0.24 & 0.29 & 0.44 \\
T1 Q & 10 & 9 & 4.34 & 4.58 & 0.77 & 0.85 & 0.77 & 0.89 & 0.22 & 0.14 & 0.40 & 0.23 \\
T2 C & 6 & 8 & 2.15 & 3.05 & 0.45 & 0.66 & 0.58 & 0.73 & 0.44 & 0.29 & 0.60 & 0.43 \\
T2 Q & 11 & 10 & 3.79 & 3.41 & 0.72 & 0.66 & 0.69 & 0.66 & 0.25 & 0.29 & 0.40 & 0.42 \\
T3 C & 8 & 9 & 3.13 & 4.84 & 0.65 & 0.85 & 0.72 & 0.89 & 0.30 & 0.14 & 0.48 & 0.24 \\
T3 Q & 15 & 12 & 5.21 & 4.83 & 0.74 & 0.84 & 0.63 & 0.77 & 0.27 & 0.19 & 0.43 & 0.32 \\
T4 C & 9 & 8 & 3.56 & 3.69 & 0.42 & 0.62 & 0.44 & 0.69 & 0.56 & 0.31 & 0.73 & 0.47 \\
T4 Q & 13 & 11 & 4.88 & 4.03 & 0.67 & 0.73 & 0.60 & 0.70 & 0.34 & 0.28 & 0.55 & 0.48 \\
T5 C & 7 & 4 & 3.07 & 2.49 & 0.55 & 0.40 & 0.65 & 0.66 & 0.39 & 0.48 & 0.60 & 0.69 \\
T5 Q & 11 & 8 & 3.91 & 3.05 & 0.58 & 0.54 & 0.55 & 0.60 & 0.44 & 0.38 & 0.64 & 0.52 \\
\hline
\end{tabular}

$\mathrm{S}=$ Genre richness, $\mathrm{D}_{\mathrm{Mg}}=$ Margalef's diversity index; $\mathrm{H}^{\prime}=$ Shanon-Wiener's diversity index; $\mathrm{J}^{\prime}=$ Pielou equity index; $\lambda=$ Simpson's dominance index; $\mathrm{D}=$ Berger-Parker's dominance index; T=Treatament; $\mathrm{P}=$ Depth; $1=0-5 \mathrm{~cm}$ depth; $2=15-20 \mathrm{~cm}$ depth; $\mathrm{C}=\mathrm{control}$ plots; $\mathrm{Q}=$ prescribed burn plots.

According to the dendrogram of the coefficient of similarity $(\mathrm{Ij})$, the maximum diversity was observed in the $0-5 \mathrm{~cm}$ layer $(83 \%)$ for T0 and T2, for the control plots and plots with prescribed burn. However, the minimum percentage of $31 \%$ was observed between the control plots, in treatments 0 and 5 (Figure 1A). At the 15-20 cm layer and between the burned plots of treatments 0 and 1 , the maximum value of similarity (Ij) was $82 \%$ and inversely proportional to the control plots of treatments 0 and 5, which were were around $12.5 \%$ (Figure 1B ).

According to the dendrogram (Figure 1C and D), the genotypes of fungi presented the maximum similarity proportions of $100 \%$ between Penicillium e Aspergillus which with more presence. Aureobasidium, Mortierella and Phialophora were the less present genus for both evaluated soil depths. For the 15-20 depth, the most similar fungi were Bipolaris and Alternaria, Rhizoctonia and Rhizopus.
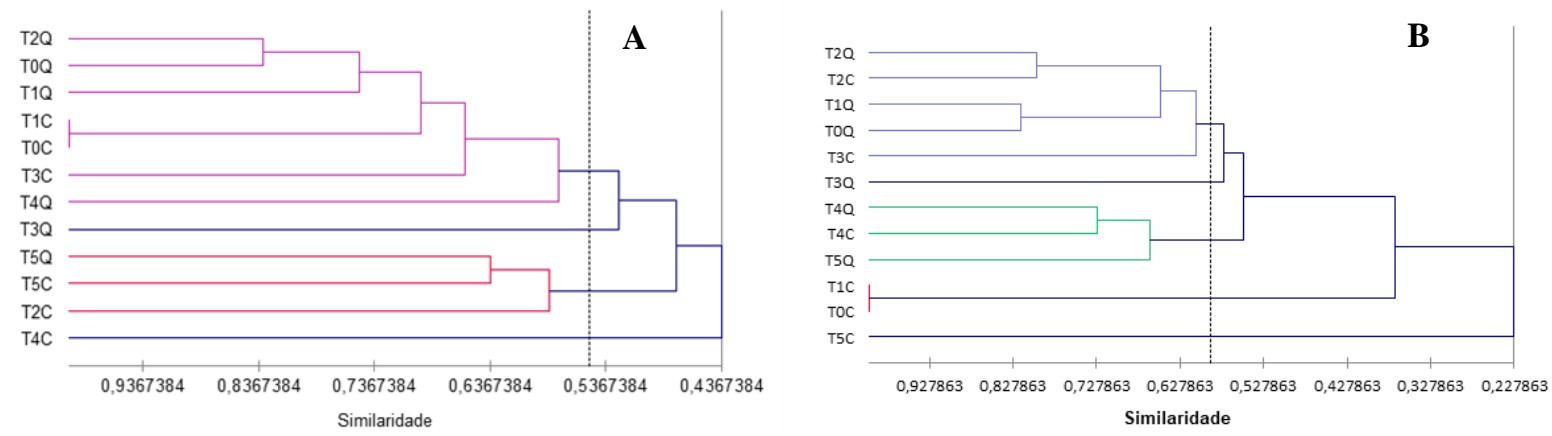

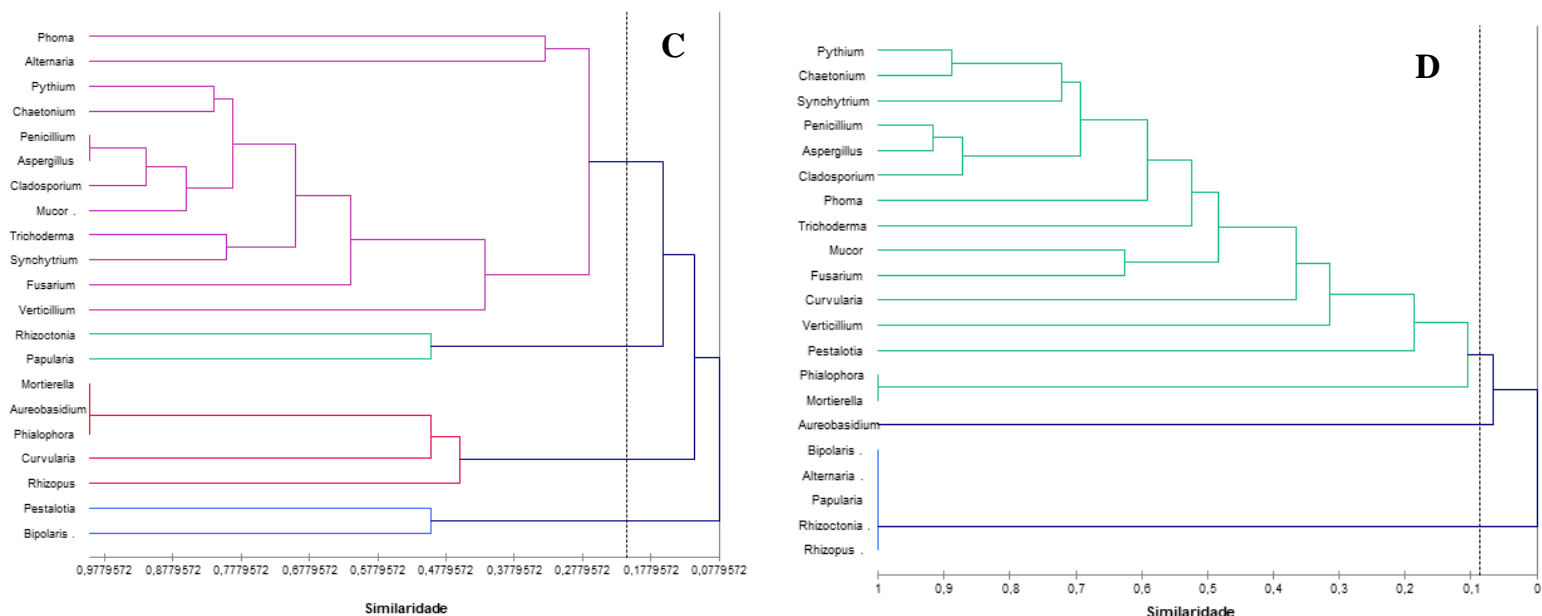

Figure 1. Dendrogram of similarity $(\mathrm{Ij})$ of $0-5 \mathrm{~cm}(\mathbf{A})$ and $15-20 \mathrm{~cm}(\mathbf{B})$ soil depths. Dendrogram of similarity between genera $(\mathrm{Ij})$ of the $0-5 \mathrm{~cm}(\mathbf{C})$ and $15-20 \mathrm{~cm}(\mathbf{D})$ soil depths.

Figura 1. Dendrograma de similaridade (Ij) das profundidades: 0-5 cm (A) e 15-20 cm (B). Dendrograma de similaridade entre gêneros $(\mathrm{Ij})$ das profundidades de $0-5 \mathrm{~cm}(\mathbf{C})$ e $15-20 \mathrm{~cm}(\mathbf{D})$.

\section{DISCUSSION}

According to Santos and Maia (2013), microorganisms are used in the study of soil quality due to the capacity to give a fast reponse according to soil changes. Regarding the experiment, in the T1 treatment performed 24 hours after the prescribed firing, it was verified that the meteorological variables did not suffer significant variations according to the conditions observed during the burning period on the previous day, being thus considered similar. However, in spite of this similarity, a significant reduction of $32.3 \%$ in total abundance $\left(\mathrm{UFC}_{\mathrm{g}} \mathrm{g}^{-1}\right)$, of fungi in the superficial layer $(0-5 \mathrm{~cm})$ and $11,9 \%$ in a deeper soil profile $(15-20 \mathrm{~cm})$ in the burned plots in relation to the control plots were observed. The reduction recorded may be related to the biomass attributes, activity and $\mathrm{CO}_{2}$, considered very sensitive to the fire effect as demonstrated in literature.

In a study carried out in a pasture area, Vieira et al. (2016) observed a significant reduction of the microbial biomass $(80 \%)$ of the $0-5 \mathrm{~cm}$ soil layer where vegetation was burned, when compared to the result found at the same soil depth, with no burning practice.

In the subsequent treatments (T2, T3 and T4, respectively) the samples were collected during the rainy season (beginning, middle and final), with the following cumulative precipitation values: $196.8 \mathrm{~mm}$ (T2); 562 $\mathrm{mm}$ (T3) and $177.2 \mathrm{~mm}$ (T4) (INMET, 2015). During this period it was observed that in some treatments there was variation, with the indexes of richness and diversity, equity and dominance of fungi in the period due to rainfall. The importance of precipitation in studies such as this one is that it is a variable that has a direct influence on the abundance and richness of fungi in native vegetation (LAZAROTTO, 2014).

The highest values of abundance of micro-fungi in the most superficial layer of the soil $(0-5 \mathrm{~cm})$ were observed in the treatment of four months after burning (T3), being 109,640 CFU.g- ${ }^{-1}$. In relation to the $15-20 \mathrm{~cm}$ depth, the highest microfungi population index value in the burned plots was observed in the treatment with two months after burning (T2). At the end of the rainy season (when the precipitation reduced 68\%), in the superficial layer, there was a population decrease of microfungi to 77,520 $\pm 40,575.81$ of CFU.g $^{-1}$, while in the $15-20 \mathrm{~cm}$ depth the inverse occurred, with an increase of $29 \%$ in relation to T3.

There are reports in the literature of immediate effects after fire, such as biomass reduction, reduction of catalytic activity and species richness. The impacts on microorganisms are higher in the soil surface horizons, due to the fact that the microbial population tends to be more abundant in these layers (REDIN et al., 2011).

In the Sensu Stricto Cerrado, a study on the microfauna properties (protozoa), in a period of three months after the fire, revealed favorable conditions for the populations of these microorganisms, similar to control plots. According to the authors' conclusion, the fire would not have caused significant changes in the structure of the protozoan community, but only the initial reduction in population density, evidencing that these microorganisms are adapted to environmental conditions imposed by the fire application (PIEROZZI et al., 2016).

In the contingency of fungal microflora populations as a function of sampling time after vegetation burn, variation in microfungal community composition was observed in the two layers evaluated in relation to the evaluated characteristics. The amount and the fungi genera varied in the different treatments, being the

FLORESTA, Curitiba, PR, v. 50, n. 1, p. 1113 - 1122, jan/mar 2020.

Santos, G. R. et.al.

ISSN eletrônico 1982-4688

DOI: 10.5380/rf.v50 i1.61754 
majority of the observed genera typical of soil, being some considered of agronomic importance due to its phytopathogenic or for being antagonistic.

It was observed a difference between the control plots with those with prescribed burning regarding the numerical richness of genre. In the period of higher precipitation, the burned plots presented the highest number of genera at the two depths, $0-5$ and $15-20 \mathrm{~cm}$, with a total of 15 and 12 genera, in the treatment T3, with 4 months after burning. Treatment 4 (T4), with 6 months after burning, was the second in diversity of genera in the two depths. Garcia et al. (2015) carried out a study in native vegetation (dense forests and Cerrado) on the soil microfungi in the rainy season and in the dry season, beng able to identify 17 genera present in the soil, 12 from the rainy season and 11 genera in the dry season. According to Meira Junior (2017), the occurrence of fire prevails the development of species that are resistant to temperature, and because there is a small number of species, the diversity is consequently reduced with a tendency to local homogeneity.

The diversity, equity and dominance indices between the 20 plots (burned and control), at the $0-5 \mathrm{~cm}$ depth showed no alterations. At the $15-20 \mathrm{~cm}$ depth, the values of the equity index $\left(J^{\prime}=0.48\right)$ and Simpson dominance $(\lambda=0.52)$ showed a higher proportion of a genus before the burning practice. According to the Berger Parker index, this result was attributed to the genus Aspergillus that presented $71 \%$ of incidence. Garcia et al. (2015), analyzing the diversity of fungi in the Tangará da Serra region, at the $0-20 \mathrm{~cm}$ soil depth in Cerrado covered with native vegetation, found Penicillium as dominant, with a $28 \%$ of incidence in the samples, followed by Trichoderma, with $18 \%$ dominance. These results are different from those found in this present study.

For all treatments, the values of Margalef and Shanon-Wiener diversity in the burned plots were higher in T3 and T4 $(\mathrm{DMg}=5.21,4.88)$. In T2, the Margalef index presented a lower value $(\mathrm{DMg}=2.15)$.

An example of how the use of fire by burnings prescribed in vegetation management causes interference in communities of soil micro-fungi can be given by the study of Oliver et al. (2015) where they describe that long-term burns and different regimes for nearly a quarter of a century in the forests of the Southwest of the United States have demonstrated that such practice does not affect the richness and diversity of soil fungi communities, in contrast with what was observed in areas with burnings with frequencies of 2 and 3 years, that presented lower diversity.

Even with the passage of fire, the values obtained with the application of the Margalef and ShanonWiener diversity indexes in the burned plots showed that the diversity of micro-fungi in the soil continued to be medium-high, demonstrating the significant diversity that can be found in soils of native vegetation of Brazilian biomes, as in the case of the Cerrado biome. To exemplify how diversity differs in distinct types of vegetation, we can cite the results found by Lazzarotto et al. (2014) who, by comparing the richness and abundance of fungi of a native forest and a monoculture of eucalyptus, found by the application of the Shannon-Wiener Index the values of $\mathrm{H}^{\prime}=1.55$ for the first environment and $\mathrm{H}^{\prime}=0.62$ for the second.

After the fire passage, the equity, ie, the pattern of the individuals among the species were normalized and consequently the index of dominance of Simpson, except in the control plots and T2 (2 months after burning) in which there was domain of Aspergillus. A similar occurrence was observed in the control and precribed burned for the $0-5 \mathrm{~cm}$ layer, in T4 and T5, which showed dominance of the Aspergillus (73\%) and Chaetonium $(60 \%)$ genus.

In relation to the fungi genus, the dendrogram showed the maximum similarity proportions of $100 \%$ between Penicillium and Aspergillus, being these, therefore, the most present genera. Aureobasidium, Mortierella and Phialophora were the least present genera, at the $0-5 \mathrm{~cm}$ of soil depth. Cavalcanti et al. (2006) carried out research on soils in the Caatinga ecosystem, collected samples at both the surface and $20 \mathrm{~cm}$ depth, isolating 1,230 colony forming units (CFU) that were represented by species of the genus Aspergillus. At the depth of 15-20 cm, the most similar fungi were Bipolaris and Alternaria, Rhizoctonia and Rhizopus. All four genera are considered disease-causing pathogens in cultivated plants. There was also a $100 \%$ similarity between Alternaria, Papularia, Rhizoctonia and Rhizopus; and between Mortierella and Phialophora. Kutorga et al. (2012) studied fungal communities after a Pinus mugo fire on the Curonian Spit peninsula in western Lithuania and determined that the temporary succession of fungal communities after the fire kept all taxonomic and functional groups defined.

\section{CONCLUSIONS}

- Fluctuations in fungal diversity in the soil over time were not affected by fire, but by the seasonality of precipitation rates during treatments after burning.

- The diversity found was considered medium-high, according to the results of the indexes used and comparative with studies in the literature. 
- Equity analysis between control and burned plots resulted in higher values of fungal diversity for burnings, demonstrating, for reasons not identified in this study, that there is a tendency for diversity to increase over a given period of time in Cerrado areas that were burned.

- The variation of seasonal rainfall showed that this meteorological variable has a greater influence on the soil fungi community than the fire passage in burning practices.

\section{REFERENCES}

BATISTA, A. C.; BEUTling, A.; PEREIRA, J. F. Estimativa do comportamento do fogo em queimas experimentais sob povoamentos de Pinus elliottii. Revista Árvore, Viçosa, v.37, n.5, p. 779-787, 2013.

BORGES, S. L.; ELOY, L.; SCHMIDT, I. B.; BARRADAS, A. C. S.; SANTOS, I. A. Manejo do fogo em veredas: novas perspectivas a partir dos sistemas agrícolas tradicionais no Jalapão. Ambiente \& Sociedade, São Paulo, v. XIX, n. 3, p. 275 - 300, 2016.

BROWN, J. K.; OBERHEU R. D.; JOHNSTON C. M. Handbook for inventorying surface fuels and biomass in the Interior West. Gen. Tech. Rep. INT-129. Ogden, UT: US Department of Agriculture, Forest Service, Intermountain Forest and Range Experimental Station. 1982, p. 1-22.

BYRAM, G. M. Combustion of forest fuels. In: DAVIS, K. P. Forest fire: Control and use. New York: Mc Graw Hill, 1959, p. 77-84.

CAVAlCANTI, M. A. D. Q.; OLIVEIRA, L. G. D.; FERNANDES, M. J.; LIMA, D. M. Filamentous fungi isolated from soil in districts of the Xingó region, Brazil. Acta Botanica Brasilica, São Paulo, v. 20, n. 4, p. 831 - 837, 2006.

DHINGRA, O. D.; SINClAIR, J. B. Basic Plant Pathology Method $2^{\text {nd }}$ ed. Boca Raton FL. CRC Lewis Publishers. 1985. 434 p.

DÍAZ-RAVIÑA, M.; MARTÍN, A.; BARREIRO, A.; LOMBAO, A.; IGLESIAS, L.; DÍAZ-FIERROS, F.; CARBALLAS, T. Mulching and seeding treatments for post-fire soil stabilisation in NW Spain: short-term effects and effectiveness. Geoderma, Amsterdam, v. 191, p. 31-39, 2012.

EMPRESA BRASILEIRA DE PESQUISA AGROPECUÁRIA (EMBRAPA). Centro Nacional de Pesquisa de Solos. Sistema Brasileiro de Classificação de Solos. Brasília, DF. 3 ed. 2013. 353 p.

GARCIA, W. M; ZAGO, B. W.; SILVA, J. R.; CARVALHO, I. F. Diversity of filamentous fungi in Cerrado soil under native vegetation. Brazilian Journal of Biosciences, Porto Alegre, v. 13, n. 4, p. 245-249, 2015.

GRIFFIN, G. F.; FRIEDEL, M. H. Effects of fire on central Australian rangelands I: fire and fuel characteristics and changes in herbage and nutrients. Australian Journal of Ecology, Carlton, v. 9, n. 4, p. 381 - 393, 1984.

INSTITUTO NACIONAL DE METEROLOGIA (INMET). Banco de Dados Meteorológicos para Ensino e Pesquisa (BDMEP) [online]. Brasília: INMET, 2015. Disponível em: <http://www.inmet.gov.br/portal/index.php?r=bdmep/bdmep>. Acesso em: 20/03/2018.

KANIESKI, M. R.; LONGHI, S. J.; NARVAES, I. S.; SOARES, P. R. C.; LONGHI-SANTOS, T.; CALLEGARO, R. M. Diversidade e padrões de distribuição espacial de espécies no estágio de regeneração natural em São Francisco de Paula, RS, Brasil. Floresta, Curitiba, v. 42, n. 3, p. 509 - 518, 2012.

KUTORGA， E.; ADAMONYTE்， G.; IRŠE்NAITĖ， R.; JUZĖNAS， S.; KASPARAVICIUS, J.; MARKOVSKAJA, S.; MOTIEJŪNAITĖ, J; TREIGIENĖ, A. Wildfire and post-fire management effects on early fungal succession in Pinus mugo plantations, located in Curonian Spit (Lithuania). Geoderma, Amsterdam, v. 191, p. 70-79, 2012.

LAZAROTTO, D. C.; PUTZKE, J.; SILVA, E. R.; PASTORINI, L. H.; PELEGRIN, C. M. G.; PRADO, G. R.; CARGNELUTTI, D. Comunidade de fungos Agaricomycetes em diferentes sistemas florestais no noroeste do Estado do Rio Grande do Sul, Brasil: Floresta Estacional Decídua e monocultura de eucalipto. Hoehnea, São Paulo, v. 41, n. 2, p. 269 - 275, 2014.

MAGGURAN, A. E. Medindo a diversidade biológica. Curitiba: Ed. UFPR, 2011, 261 p.

MEIRA JUNIOR, M. S.; PEREIRA, I. M.; MACHADO, E. L. M.; MOTA, S. da L. L.; RIBEIRO, P. S. S. de P.; OTONI, T. J. O. Impacto do Fogo em Campo Sujo no Parque Estadual do Biribiri, Minas Gerais, Brasil. Floresta e Ambiente, Seropédica, v. 24, n. 00110814, p. 1 - 9, 2017.

FLORESTA, Curitiba, PR, v. 50, n. 1, p. 1113 - 1122, jan/mar 2020.

Santos, G. R. et.al.

ISSN eletrônico 1982-4688

DOI: $10.5380 /$ rf.v50 i1.61754 
OLIVER, A. K.; CALLAHAM J. R., M. A. Y JUMPPONEN B. Soil fungal communities respond compositionally to recurring frequent prescribed burning in a managed southeastern US forest ecosystem. Forest Ecology and Management, Amsterdam, v. 345, p. 1- 9, 2015.

PIEROZZI, M.; JAVAROTI, D. D. da C.; SELEGHIM, M. H. R. Effects of fire stress to soil protozoan abundance and richness in a Brazilian savanna. Revista Brasileira de Zoociências, Juiz de Fora, v. 17, n. 1, p. 91 111,2016

REDIN, M.; SANTOS, G. F.; MIGUEL, P.; DENEGA, G. L.; LUPATINI, M.; DONEDA, A.; SOUZA, E. L. Impactos da queima sobre atributos químicos, físicos e biológicos do solo. Ciência Florestal, Santa Maria, v.21, n.2, p. 381-392, 2011.

RIBEIRO, J. F.; WALTER, B. M. T. As principais Fitofisionomias do Bioma Cerrado. In: SANO. S. M.; ALMEIDA, S. P.; RIBEIRO, J. F. Cerrado: ecologia e flora. Embrapa: Brasília/DF, 2008. 1279 p.

RODRIGUES, W. C. DivEs - Diversidade de Espécies v3.0. Guia do Usuário. Entomologistas do Brasil. 2015. Disponível em <http://dives.ebras.bio.br> Acesso em: 20/01/2018.

SANTOS, V. M.; MAIA, L. C. BIOINDICADORES DE QUALIDADE DO SOLO. Anais da Academia Pernambucana de Ciência Agronômica, Recife, v. 10, p. 195-226, 2013.

SECRETARIA DE PlANEJAMENTO (SEPLAN). Atlas do Tocantins: Subsídios ao Planejamento da Gestão Territorial. 2012. Disponível em: 〈https://goo.gl/cCBJ3d〉. Acesso em: 20 fev. 2018.

SHEN, J. P., CHEN, C. R., LEWIS, T. Long term repeated fire disturbance alters soil bacterial diversity but not the abundance in an Australian wet sclerophyll forest. Scientific Reports, New Delhi, v. 6, n. 19639, p. 1-10, 2016.

VIEIRA, A. C.; MELlONI, R.; MELlONI, E. G. P.; GUIMARÃES, M. C.; FREITAS, M. S.; PECORARO, D. Fogo e seus efeitos na qualidade do solo de pastagem. Revista Brasileira de Geografia Física, Recife, v. 9, n. 6, p. 1703-1711, 2016. 